\title{
MODIFICAÇÃO SIMPLES E RÁPIDA DO MÉTODO DE PAL-WEIGERT PARA A COLORAÇÃO DAS BAINHAS DE MIELINA
}

\author{
Eros Abrantes Erhart*
}

Esta técnica permite controlar a formação da laca que cora as bainhas de mielina, quando se usam um mordente e a hematoxilina; apresenta ainda as vantagens de ser rápida e muito simples. Cora em azul-preto as bainhas de mielina, sôbre fundo pálido descorado. 0 material fixado em formol dá resultados igualmente bons para cortes de parafina, de celoidina e de congelação.

Os cortes são tratados do seguinte modo (os de parafina são prèviamente desparafinados e re-hidratados): 1) lavar em água; 2) transferir para uma solução aquosa de alúmen de ferro a $4 \%$, durante 2 a 3 minutos; 3) retirar o excesso de alúmen de ferro por passagem rápida em água; 4) corar 5 a 20 minutos, à temperatura ambiente, na seguinte solução: água $80 \mathrm{ml}$, carbonato de lítio $1 \mathrm{~g}$, hematoxilina alcoólica a $10 \%$, 20. $\mathrm{ml}$.

Logo após imergidos na solução corante, os cortes cobrem-se com espêssa laca que ràpidamente se desfaz, deixando a substância cinzenta mais escura do que a branca. Após alguns minutos ( 5 a 20 , conforme a inclusãc e a espessura do corte), há uma inversão gradual dêste aspecto, isto é, a substância cinzenta torna-se clara e a branca, escura. Examinando-se o corte contra a luz, repetidas vêzes, podem-se acompanhar essas modificações até o ponto em que a subștância cinzenta se torna clara e trans. parente e a substância branca, azul-negra.

Terminada a fase de coloração, termina-se o preparado com: 5) lavagem várias vêzes em água; 6) desidratação, diafanização e montagem em bálsamo.

\footnotetext{
* Assistente do Departamento de Anatomia da Fac. Med. da Univ. de São Paulo (Prof. R. Lochi).

Nota da Redação - Este trabalho, com exceção das fotomicrografias, foi publicado em inglês, sob o título: A simple, fast, controllable modification of Pal-Weigert's stain for myelin sheaths. Ztschr. f. wissensch. Mikr. u. mikr. Technik, $60(3 / 4): 155-156,1951$.
} 
Qualquer excesso de tempo na solução corante. (fase 4) pode redundar em diferenciação excessiva; nesse caso não haverá desvantagens em se reiniciar todo o processo, a partir da fase 1 .
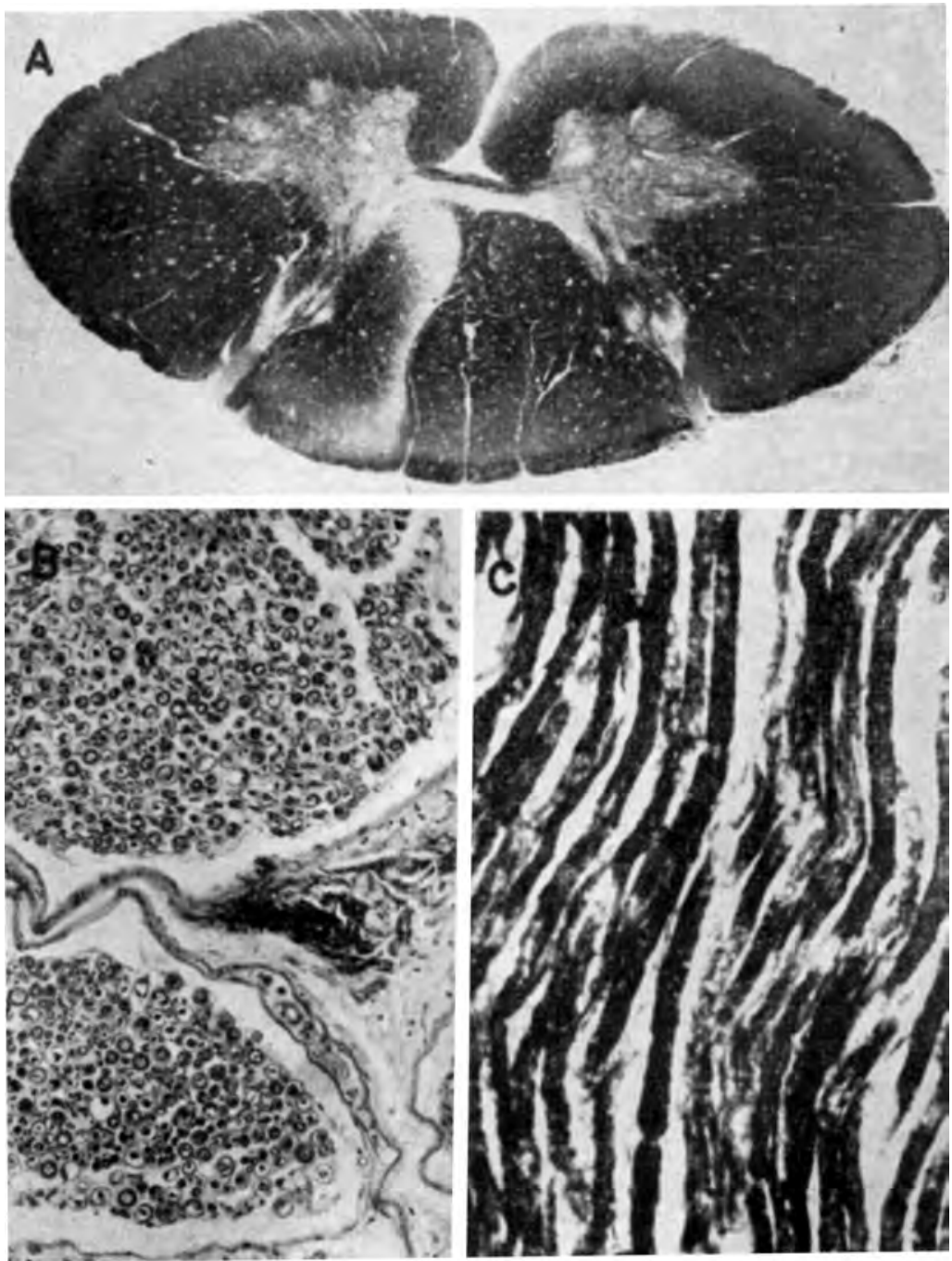

Fig. 1 - Em A, corte de celoidina: secção transversal da medula cervical humana, com degeneração parcial do fasciculus cuneatus (x 10). Em B, corte de parafina: seç̧ão transversal de nervo ciático de cavalo, vendo-se claramente os anéis de mielina nas fibras finas, médias e grossas $(x 300)$. Em $C$, corte de congelação: secção longitudinal de raiz do plexo braquial humano, notando-se vários nodos de Ranvier (x 300). 
A solução alcoólica de hematoxilina a $10 \%$ pode ser fresca ou de estoque, mas a solução corante deve ser preparada no momento, pois se altera após 24-36 horas. Esta última pode ser usada para grande número de cortes.

Resultados - Bainhas de mielina, azul-negro; células nervosas, amarelo-palha a cinzento; nucléolos e eritrócitos, negro. O fundo é transparente e pràticamente incolor.

Como é sahido, parte da mielina se perde pela fixação em formol; essa perda é muito mais acentuada quando da inclusão em parafina ou celoidina. Em tais casos, e especialmente quando se trabalha com cortes finos (5.10 micra), a diferenciação correta resulta em palidez excessiva da preparação. Pode-se preferir assim uma diferenciação menor; mas, então, os cilindros-eixos e núcleos gliais podem reter a laca, aparecendo em negro, devido à insuficiência da diferenciação.

Por outro lado, a congelação não acarreta perda de mielina, mas essa vantagem nem sempre contrabalança as restrições dêsse método de rotina.

A coloração do fundo é optativa, podendo-se usar carmim, picrocarmim, safranina, cresil violeta, etc.

Não foi encontrada referência alguma a técnica idêntica nos índices bibliográficos e livros especializados.

Departamento de Anatomia da Fac. Med. da Univ. de São Paulo. 